\title{
FILSAFAT ILMU DALAM IPTEK
}

\author{
I Kadek Noppi Adi Jaya \\ iknadijaya@gmail.com \\ Fakultas Teknologi Informasi dan Sains \\ Program Studi Sistem Informasi
}

\section{Pendahuluan}

Perkembangan teknologi telah memberikan pengaruh terhadap dunia pendidikan khususnya dalam proses pembelajaran. Teknologi Informasi dan Komunikasi (TIK) sebagai bagian dari ilmu pengetahuan dan teknologi (IPTEK) secara umum adalah semua yang teknologi berhubungan dengan pengambilan, pengumpulan (akuisisi), pengolahan, penyimpanan, penyebaran, dan penyajian informasi. Bahkan sampai awal abad ke-21 ini, dipercaya bahwa bidang TIK masih akan terus pesat berkembang dan belum terlihat titik jenuhnya sampai beberapa dekade mendatang. Pada tingkat global, perkembangan TIK telah mempengaruhi seluruh bidang kehidupan umat manusia. Intrusi TIK ke dalam bidang-bidang teknologi lain telah sedemikian jauh sehingga tidak ada satupun peralatan hasil inovasi teknologi yang tidak memanfaatkan perangkat TIK.

\section{Permasalahan}

Sikap dasar yang selalu bertanya menjadi ciri filsafat, menurun pada berbagai cabang ilmu yang semula berinduk padanya. Karenanya, dalam semua ilmu terdapat kecenderungan dasar itu. Manakala ilmu mengalami masalah yang sulit dipecahkan, ia akan kembali pada filsafat dan memulainya dengan sikap dasar untuk bertanya. Dalam filsafat, manusia mempertanyakan apa saja dari berbagai sudut, secara totalitas menyeluruh, menyangkut hakikat inti, sebab dari segala sebab, mancari jauh ke akar, hingga ke dasar.

Membicarakan pengaruh TIK pada berbagai bidang lain tentu memerlukan waktu diskusi yang sangat panjang. Dalam makalah ini, kaitan filsafat dengan TIK akan di bahas tanpa mengecilkan pengaruh TIK di bidang lain, bidang pembelajaran mendapatkan manfaat lebih dalam kaitannya 
dengan kemampuan TIK mengolah dan menyebarkan informasi.

\section{Pembahasan}

\section{A. Landasan Ontologi dalam TIK}

Di dalam ontologi merupakan studi tentang ada yang universal, dengan mencari pemikiran semesta universal. Ontologi berusaha mencari inti yang termuat dalam setiap keyataan atau menjelaskan yang ada dalam setiap bentuknya. Dalam ontologi merupakan studi yang terdalam dari setiap hakekat kenyataan, seperti dapatkah manusia sunguh-sungguh memilih, apakah ada Tuhan, apakah nyata dalam hakekat material ataukah spiritual, apakah jiwa sungguh dapat dibedakan dengan badan.

Ontologi ilmu membatasi diri pada ruang kajian keilmuan yang bisa dipikirkan manusia secara rasional dan yang bisa diamati melalui panca indera manusia.

\section{B. Landasan Epistemologi dalam TIK}

Epistemologi merupakan cabang filsafat yang menyelidiki asal, sifat, metode dan batasan pengetahuan manusia (a branch of philosophy that investigates the origin, nature, methods and limits of human knowledge). Epistemologi juga disebut teori pengetahuan (theory of knowledge). berasal dari kata Yunani episteme, yang berarti "pengetahuan", "pengetahuan yang benar", "pengetahuan ilrniah", dan logos = teori. Epistemologi dapat didefmisikan sebagai cabang filsafat yang mempelajari asal mula atau sumber, struktur, metode dan sahnya (validitas) pengetahuan.

Epistemologi, studi tentang asal usul hakekat dan jangkauan pengetahuan. Apakah pengalaman merupakan satusatunya sumber pengetahuan. Apakah yang menyebabkan suatu keyakinan benar dan yang lain salah. Adakah soalsoal penting yang tidak dapat dijawab dengan sains dan dapatkah kita mengetahui pikiran dan perasaan orang lain. Pengkajian dari epistemologi adalah hakekat pengetahuan yang terdiri empat pokok persoalan pengetahuan seperti keabsahan, struktur, batas dan sumber.

\section{Landasan Aksiologi dalam TIK}

Aksiologi ialah menyangkut masalah nilai kegunaan ilmu. Ilmu tidak bebas nilai. Artinya pada tahap-tahap tertentu kadang ilmu harus disesuaikan dengan nilai-nilai budaya dan moral suatu masyarakat, sehingga nilai kegunaan ilmu tersebut dapat dirasakan oleh masyarakat dalam usahanya meningkatkan kesejahteraan bersama, 
bukan sebaliknya malahan menimbulkan bencana.

Aksiologi diartikan sebagai teori nilai yang berkaitan dengan kegunaan dari pengetahuan yang diperoleh.

\section{Kaitan antara Filsafat Ilmu} dengan Teknologi Informasi dan Komunikasi

Para ahli sepakat bahwa landasan ilmu komunikasi yang pertama adalah filsafat. Filsafat melandasi ilmu komunikasi dari domain ethos, pathos, dan logos dari teori Aristoteles dan Plato. Ethos merupakan komponenfilsafat yang mengajarkan ilmuwan tentang pentingnya rambu-rambu normative dalam pengembangan ilmu pengetahuan yang kemudian menjadi kunci utama bagi hubungan antara ilmu dan masyarakat. Pathos merupakan komponen filsafat yang menyangkut aspek emosi atau rasa yang ada dalam diri manusia sebagai makhluk yang senantiasa mencintai keindahan, penghargaan, yang dengan ini manusia berpeluang untuk melakukan improvisasi dalam pengembangan ilmu pengetahuan. Logos merupakan komponen filsafat yang membimbing para ilmuwan untuk mengambil suatu keputusan berdasarkan pada pemikiran yang bersifat nalar dan rasional, yang dicirikan oleh argument-argumen yang logis. Komponen yang lain dari filsafat adalah komponen piker, yang terdiri dari etika, logika, dan estetika, Komponen ini bersinegri dengan aspek kajian ontologi (keapaan), epistemologi (kebagaimanaan), dan aksiologi (kegunaan atau kemanfaatan).

Pada dasarnya filsafat komunikasi memberikan pengetahuan tentang kedudukan Ilmu Komunikasi dari perspektif epistemology:

1. Ontologis

Ontologi berarti studi tentang arti "ada" dan "berada", tentang cirri-ciri esensial dari yang ada dalam dirinya sendiri, menurut bentuknya yang paling abstrak. Ontolgi sendiri berarti memahami hakikat jenis ilmu pengetahuan itu sendiri yang dalam hal ini adalah Ilmu Komunikasi.

Ontologi. Pertanyaan yang menyangkut wilayah ini antara lain: Apakah ilmu komunikasi? Apakah yang ditelaah oleh ilmu komunikasi? Apakah objek kajiannya? Bagaimanakah hakikat komunikasi yang menjadi objek kajiannya?

Ilmu komunikasi dipahami melalui objek materi dan objek formal. Secara ontologism, Ilmu komunikasi sebagai objek materi dipahami 
sebagai sesuatu yang monoteistik pada tingkat yang paling abstrak atau yang paling tinggi sebagai sebuah kesatuan dan kesamaan sebagai makhluk atau benda. Sementara objek forma melihat Ilmu Komunikasi sebagai suatu sudut pandang (point of view), yang selanjutnya menentukan ruang lingkup studi itu sendiri.

2. Epistemologis

Hakikat pribadi ilmu (Komunikasi) yaitu berkaitan dengan pengetahuan mengenai pengetahuan ilmu (Komunikasi) sendiri atau Theory of Knowledge. Persoalan utama epsitemologis Ilmu Komunikasi adalah mengenai persoalan apa yang dapat ita ketahui dan bagaimana cara mengetahuinya, "what can we know, and how do we know it?". Menurut Lacey, hal-hal yang terkait meliputi "belief, understanding, reson, judgement, sensation, imagination, supposing, guesting, learning, and forgetting".

Epistemologi. Pertanyaan yang menyangkut wilayah ini antara lain: Bagaimana proses yang memungkinkan ditimbanya pengetahuan menjadi ilmu? Bagaimanakah prosedurnya, metodologinya? Hal-hal apa yang harus diperhatikan agar bisa mendapat pengetahuan dan ilmu yang benar dalam hal komunikasi? Apa yang dimaksud dengan kebenaran? Apakah kriteria kebenaran dan logika kebenaran dalam konteks ilmu komunikasi?

Secara sederhana sebetulnya perdebatan mengenai epistemology Ilmu Komunikasi sudah sejak kemunculan Komunikasi sebagai ilmu. Perdebatan apakah Ilmu Komunikasi adalah sebuah ilmu atau bukan sangat erat kaitannya dengan bagaimana proses penetapan suatu bidang menjadi sebuah ilmu. Dilihat sejarahnya, maka Ilmu Komunikasi dikatakan sebagai ilmu tidak terlepas dari ilmu-ilmu social yang terlebih dahulu ada. pengaruh Sosiologi dan Psikologi sangat berkontribusi atas lahirnya ilmu ini. Bahkan namanama seperti Laswell, Schramm, Hovland, Freud, sangat besar pengaruhnya atas perkembangan keilmuan Komunikasi. Dan memang, Komunikasi ditelaah lebih jauh menjadi sebuah ilmu baru oada abad ke-19 di daratan Amerika yang sangat erat kaitannya dengan aspek aksiologis ilmu ini sendiri. 
Contoh konkret epistemologis dalam

Ilmu Komunikasi dapat dilihat dari proses perkembangan kajian keilmuan Komunikasi di Amerika (Lihat History of Communication, Griffin: 2002). Kajian Komunikasi yang dipelajari untuk kepentingan manusia pada masa peperangan semakin meneguhkan Komunikasi menjadi sebuah ilmu.

3. Aksiologis

Hakikat individual ilmu pengetahuan yang bersitaf etik terkait aspek kebermanfaat ilmu itu sendiri. Seperti yang telah disinggung pada aspek epistemologis bahwa aspek aksiologis sangat terkait dengan tujuan pragmatic filosofis yaitu azas kebermanfaatan dengan tujuan kepentingan manusia itu sendiri. Perkembangan ilmu Komunikasi erat kaitannya dengan kebutuhan manusia akan komunikasi.

Aksiologi. Pertanyaan yang menyangkut wilayah ini antara lain: Untuk apa ilmu komunikasi itu digunakan? Bagaimana kaitan antara cara penggunaan pengetahuan dan ilmu tersebut dengan kaidah-kaidah moral? Bagaimanakah kaitan ilmu komunikasi berdasarkan pilihanpilihan moral? Bagaimana kaitan antara operasionalisasi metode ilmiah dalam upaya melahirkan dan menemukan teori-teori dan aplikasi ilmu komunikasi dengan normanorma moral dan profesional?

Kebutuhan memengaruhi (persuasive), retoris (public speaking), spreading of information, propaganda, adalah sebagian kecil dari manfaat Ilmu Komunikasi. Secara pragmatis, aspek aksiologis dari Ilmu Komunikasi terjawab seiring perkembangan kebutuhan manusia.

Filsafat bermula dari pertanyaan dan berakhir pada pertanyaan. Hakikat filsafat adalah bertanya terusmenerus, karenanya dikatakan bahwa filsafat adalah sikap bertanya itu sendiri. Dengan bertanya, filsafat mencari kebenaran. Namun, filsafat tidak menerima kebenaran apapun sebagai sesuatu yang sudah selesai. Yang muncul adalah sikap kritis, meragukan terus kebenaran yang ditemukan. Dengan bertanya, orang menghadapi realitas kehidupan sebagai suatu masalah, sebagai sebuah pertanyaan, tugas untuk digeluti, dicari tahu jawabannya.

Tidak sebagaimana dengan ilmuilmu alam yang objeknya eksak, 
misalnya dalam biologi akan mudah untuk membedakan kucing dengan anjing, mana jantung dan mana hati, sehingga tidak memerlukan pendefinisian secara ketat. Tidak demikian halnya dengan ilmu-ilmu sosial yang objeknya abstrak. Ilmu komunikasi berada dalam rumpun ilmu-ilmu sosial yang berobjek abstrak, yaitu tindakan manusia dalam konteks sosial. Komunikasi sebagai kata yang abstrak sulit untuk didefinisikan. Para pakar telah membuat banyak upaya untuk mendefinisikan komunikasi. Ilmu komunikasi sebagai salah satu ilmu sosial mutlak memberikan definisi tajam dan jernih guna menjelaskan objeknya yang abstrak itu.

Tidak semua peristiwa merupakan objek kajian ilmu komunikasi. Sebagaimana diutarakan, objek suatu ilmu harus terdiri dari satu golongan masalah yang sama sifat hakikatnya. Karena objeknya yang abstrak, syarat objek ilmu komunikasinya adalah memiliki objek yang sama, yaitu tindakan manusia dalam konteks sosial.

\section{E. Pengaruh Epistemologi terhadap TIK}

Epistemologi adalah teori pengetahuan ilmiah. Sebagai teori pengetahuan ilmiah, epistemologi berfungsi dan bertugas menganalisis secara kritis prosedur yang ditempuh ilmu pengetahuan dalam membentuk dirinya. Tetapi, ilmu pengetahuan harus ditangkap dalam pertumbuhannya, sebab ilmu pengetahuan yang berhenti, akan kehilangan kekhasannya. Ilmu pengetahuan harus berkembang terus, sehingga tidka jarang temuan ilmu pengetahuan yang lebih dulu ditentang atau disempurnakan oleh temuan ilmu pengetahuan yang kemudian.

Epistemologi juga membekali daya kritik yang tinggi terhadap konsepkonsep atau teori-teori yang ada. Dalam filsafat, banyak konsep dari pemikiran filosof yang kemudian mendapat serangan yang tajam dari pemikiran filosof lain berdasarkan pendekatanpendekatan epistemologi. Penguasaan epistemologi, terutama cara-cara memperoleh pengetahuan yang membantu seseorang dalam melakukan koreksi kritis terhadap bangunan pemikiran yang diajukan orang lain maupun oleh dirinya sendiri. Koreksi secara kontinyu terhadap pemikirannya 
sendiri ini untuk menyempurnakan argumentasi atau alasan supaya memperoleh hasil pemikiran yang maksimal. Ini menunjukkan bahwa epistemologi bisa mengarahkan seseorang untuk mengkritik pemikiran orang lain (kritik eksternal) dan pemikirannya sendiri (kritik internal). Implikasinya, epistemologi senantiasa mendorong dinamika berpikir secara korektif dan kritis, sehingga perkembangan ilmu pengetahuan relatif mudah dicapai, bila para ilmuwan memperkuat penguasaannya.

Secara global epistemologi berpengaruh terhadap peradaban manusia. Suatu peradaban, sudah tentu dibentuk oleh teori pengetahuannya. Epistemologi mengatur semua aspek studi manusia, dari filsafat dan ilmu murni sampai ilmu sosial. Epistemologi dari masyarakatlah yang memberikan kesatuan dan koherensi pada tubuh, ilmu-ilmu mereka itu—suatu kesatuan yang merupakan hasil pengamatan kritis dari ilmu-ilmu — dipandang dari keyakinan, kepercayaan dan sistem nilai mereka. Epistemologilah yang menentukan kemajuan sains dan teknologi. Wujud sains dan teknologi yang maju disuatu negara, karena didukung oleh penguasaan dan bahkan pengembangan epistemologi. Tidak ada bangsa yang pandai merekayasa fenomena alam, sehingga kemajuan sains dan teknologi tanpa didukung oleh kemajuan epistemologi.

\section{Daftar Pustaka}

[1] Keraf, A Sonny dan Mikhael Dua, 2001, Ilmu Pengetahuan, sebuah Tinjauan Filosofis, Yogyakarta: Kanisius

[2] Drs. H. Mohammad Adib, MA. 2011. Filsafat Ilmu: Ontologi, Epistemologi, Aksiologi, dan Logika Ilmu Pengetahuan. Yogyakarta: Pustaka Pelajar.

[3] Prof. Dr. Ahmad Tafsir. 2010. Filsafat Ilmu: Mengurai Ontologi, Epistemologi dan Aksiologi Pengetahuan. Bandung: PT Remaja Rosdakarya.

[4] Yuyun Suriasumantri. 2009. Ilmu dalam Perspektif: Kumpulan Karangan tentang Hakikat Ilmu. Jakarta: Gramedia.

[5] Cangara, Hafied. 2008. Pengantar Ilmu Komunikasi. Edisi Revisi. Jakarta. Raja Grafindo Persada. 